\title{
interview
}

\section{A decade of stem-cell research}

\author{
An interview with John Gearhart, Director of the Institute for Regenerative Medicine at the University \\ of Pennsylvania, USA
}

EMBO reports (ER): It is now a decade since you and James Thomson, at the University of Madison-Wisconsin, both published your papers on the derivation of human stem cells from primordial germ cells and blastocysts, respectively (Shamblott et al, 1998; Thomson et al, 1998). There was, and still is, a great deal of hope that these cells will lead to cures for various severe diseases but, ten years later, how far are we in terms of practical therapies and applications?

John Gearhart (JG): The question is very appropriate because our naysayers in Congress continue to accuse us of not having achieved anything in terms of therapies with stem cells derived from embryonic sources; and it is true. Yet, Geron Corporation [Menlo Park, CA, USA] has made a request to the US Food and Drug Administration [FDA; Rockville, MD, USA] to move forward with dendrites derived from embryonic stem [ES] cells to treat spinal cord injury. However, the FDA has been considering the submission for quite a while and it has not yet been approved, so obviously there are some concerns. The bottom line is that nothing is being used yet in humans from human ES cells, though adult stem cells are being used successfully in various therapies.

\section{ER: How close are therapies with ES cells?}

JG: This is a matter of controversy. Some people feel that it will be a matter of years. It has been an exciting time using animal models to study the use of ES cells in heart and neural tissues, but it is a huge jump to go from a laboratory animal into humans, and there are a lot of safety issues that have to be addressed. The FDA has been struggling with the safety requirements for several years, and it is naturally a very controversial, very complex situation.

I would not be surprised if we actually see more applications within the next few years, and quite a number of them will probably make it to clinical trials with derivatives of ES cells or ES-cell products - that is, some component or molecule produced by ES cells that could be important in regenerating certain tissues. I have always thought that it will not be the cells themselves that will be so important, but rather what we learn about them and the way they function.

ER: Do you think that adult or induced pluripotent stem (iPS) cells could replace ES cells for research and therapies?

JG: I absolutely feel that they can. This possibility has certainly been the cause of some excitement in the field over the past couple of years. It is possible to generate, for example, a normal neural cell or some other type of cell from iPS. Moreover, it is possible to take a cell from a patient and convert it to another type of cell-that is incredibly exciting. I think that there is a real desire among scientists in the field to move the research forward and to try various combinations and permutations of iPS cells.

The biggest hurdle that we face in terms of therapy is that we have to genetically match the patient and the cells. It simply is not feasible to meet a patient and tell them that we have these wonderful heart cell lines, but that they will have to be on immunosuppressive drugs for the rest of their life. That is just not good enough. Though I do think that the heart will be one of the first targets for a therapy utilizing ES cells.
ER: Is the current scientific interest in ES cells exaggerated and do you see it eventually waning?

JG: I think there are a number of different reasons why people work with ES cells, and I actually think that there will be more people in the field now because of the creation of iPS cells, simply because they are a much easier technology to work with; anybody can now 'sprinkle' a few genes onto cells and get into the game. I think this is a good thing; it took a while for people to learn how to work on ES cells, but iPS is a platform that many investigators can use and this will push the field forward. This is absolutely great and I applaud it; it is a development that we are all looking forward to using.

ER: How difficult has it been to obtain federal funding for your research?

JG: It has been difficult; we really began this work in 1992 and 1993. In those early years, I would try to speak to our programme officers and others at the National Institutes of Health [NIH; Bethesda, MD, USA] about funding, but no one was interested in even talking to us. Any research that involved the use of embryos or fetal tissue was very difficult to get funding for. Fortunately, I was the Head of a Division at Johns Hopkins University [Baltimore, MD, USA] and we had a reasonable sum of money of our own, including an endowment that I could use as well as small grants; but certainly no federal money.

After 1996, there was great concern during the administration of President Bill Clinton about ES-cell research, particularly following the discussions surrounding the cloning of the sheep Dolly. Congress passed an amendment to the federal legislation-known as the 


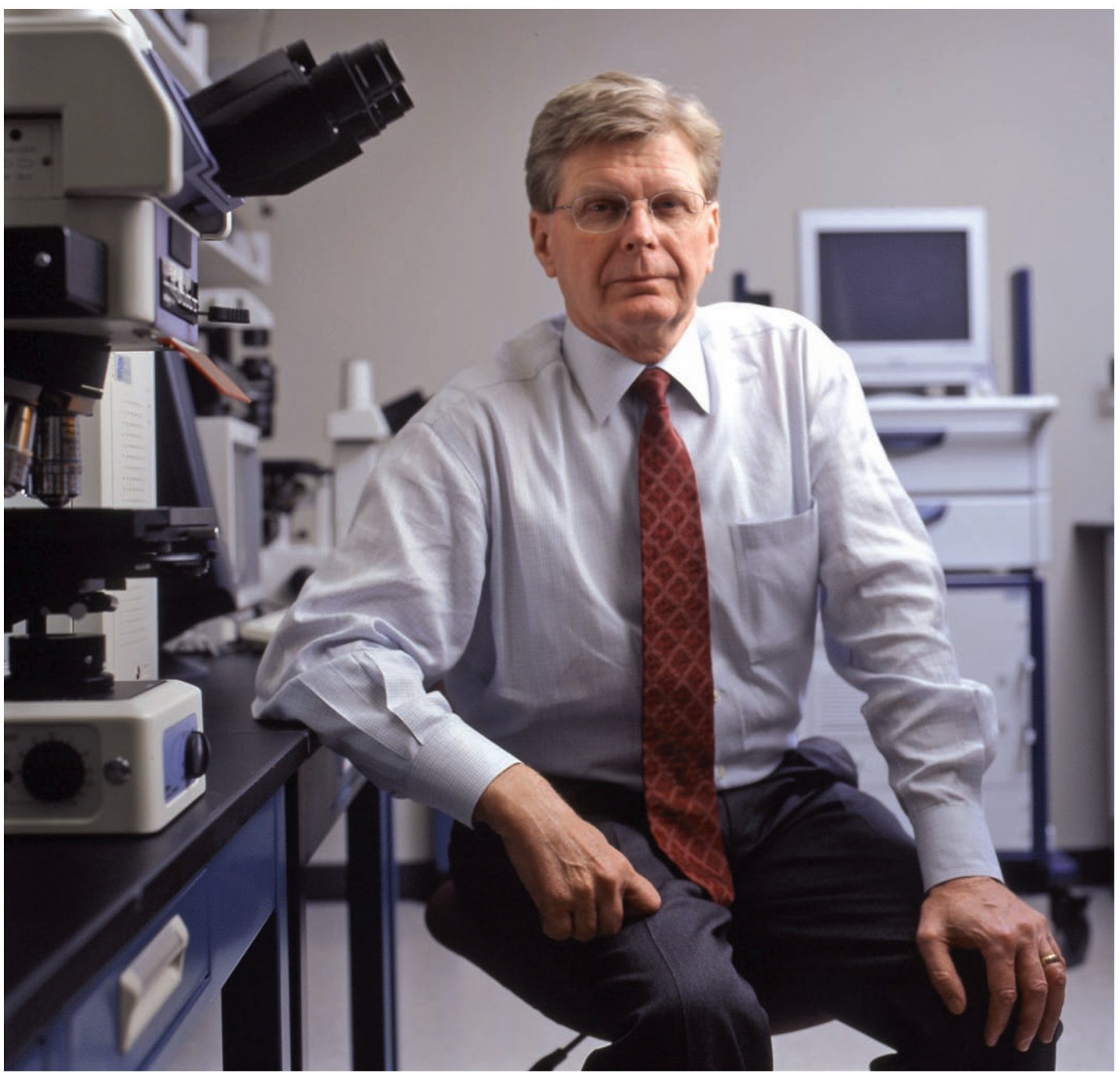

Credit: David Colwell, Johns Hopkins Medicine

Dickey-Wicker amendment-that forbids the use of federal funds for the destruction of any human embryo that is still in force today. Later, President George W. Bush implemented his own policies, and some money became available for some of this work, but it still was not much.

ER: Does the federal government distinguish between embryonic and fetal material when considering funding?
JG: Yes, and the work on human embryos is really where the focus has been. The fetal source of tissue falls under a different set of guidelines but, again, it has been extremely difficult to get money to work in this area simply because of politics. It is important to realize that the funding of medical research on anything dealing with reproduction and embryos has been off limits in the USA. We have never had a sound policy on this and we have gotten ourselves into trouble,
I think. Any time that a commission has been proposed to look at these issues and make recommendations - either through the NIH, or any other body-all US presidents have shied away from it. This trend goes back to the 1960s and 1970s.

ER: What is your view of the situation in Europe as regards ES-cell and fetal tissue research, and how does the research environment there compare to the USA? 
JG: In some European countries the research is absolutely forbidden, whereas in others it goes forward under oversight that has been in place for years. This is similar in a sense to the USA, where the regulations vary from state to state.

For example, as I stand in Pennsylvania looking out my front door, I know that there are certain things that I have to be careful about doing. There is an incredibly strong anti-abortion law here and proceeding with research on ES cells becomes a matter of interpretation of the law-is it abortion or not? The law does not actually say that you cannot do ES-cell work, but some states have put these kinds of things on their dockets and they are debating them. Of course, most of the laws that are in place have been on the books for decades and it is a matter of interpretation as to what is allowed, which can vary from state to state.

\section{ER: Is your work in jeopardy?}

JG: I do not believe it to be. It is important to note that we are abiding by President Bush's guidelines and are using approved stemcell lines; we are not generating new lines; we are not destroying any embryos; we are complying with the federal policies and with the law in Pennsylvania.

ER: There have been dire warnings that the US could lose its edge in this field and that scientists could defect to other countries owing to the laws limiting the research? Has that happened?

JG: I do not think that this has happened. Early on, there was a lot of talk about such dangers, but state initiatives have provided money for research in California, New York, New Jersey, Connecticut and Illinois. The private sector has responded generously and Michael Bloomberg, the Mayor of New York City, has supported our institute at Hopkins. So the private sector has picked up the slack, which is visible in money gifted throughout the country.

In fact, there is a general concern from many people about making sure that this research goes forward. The truth is that the US's position as a leader in this field is at risk; federal policy has really limited us in terms of competing with foreign countries where the laws are more liberal. But, no matter how generous the private sector is, we need access to federal money; the $\mathrm{NIH}$ spends billions of dollars each year and funds 85 per cent of all biomedical research in this country-private donations simply cannot compete. Many scientists and interested parties feel that we need a more progressive national policy to keep us competitive at the cutting edge of this kind of work.

\section{ER: What do you mean by competitive?}

JG: It is not just an issue of saying we are going to 'be there first' for the prestige; there are serious financial implications in terms of intellectual property. But, to own it you have to be there first and do things in advance of other people, or do things that other people have not thought of or do not have the expertise to do. These are the kinds of areas we are concerned about. How do you keep the cutting-edge cutting?

ER: Do you think that researchers in countries with more liberal laws and regulations, such as the UK, Australia or Israel, are at an advantage? Or is the US still holding the lead in stem-cell research?

JG: I would actually ask what you mean by 'the lead'? Are you counting the number of publications or the number of patents, or something else? How do you measure 'lead'? We actually have very prominent investigators in the USA that are doing terrific work at the cutting-edge in an international arena.

I think that places like California, with financial backing and legislative support, are going to be the real centres that lead the research in the USA and where you are going to see all the progress. The more liberal states are sending a message that if a scientist wants to do research into these areas, then they should come to California, or to Massachusetts, or to New York, and they will be supported. Of course, you need the funding to do it and you need the leadership to permit it to be done, but, New York, for example, is coming on line with lots of money and I think that Massachusetts probably will as well at some point.

ER: As we speak, we are weeks away from the Presidential election [that Barack Obama has since won]. Are both Barack Obama and John McCain in favour of stem-cell research?

JG: Both McCain and Obama supported changing the President's policy in 2001, meaning that we can only get federal funding on research using old cell lines. Yet, we have very good, new material becoming available that was derived without federal funding outside the country. Both have supported legislation to permit the use of additional ES lines already in existence.

However, the other day, McCain made a statement that he wanted to criminalize somatic cell nuclear transfer. The concern of many conservatives is that somatic cell nuclear transfer-in which you take the nucleus out of an adult cell and put it into an enucleated egg cell-generates an embryo specifically to be destroyed in research. McCain has been playing very strongly to the conservative base on this issue, but those of us working in the field believe that we should have this technology available to us. This is not an alternative to iPS, though we still feel that we can learn a lot by using somatic cell nuclear transfer.

ER: Do you think that the conservatives have a point about the product of somatic cell nuclear transfer being an embryo?

JG: I would agree that it has all the features of an embryo, but the purpose of creating it is to generate stem cells, not for reproductive biology, not to make a baby. So, I would argue that this is a moral or philosophical difference of opinion. However, while it is one thing to say that we should ban the use of federal funding for this research, it is a different thing altogether to say that it should be a crime and that researchers will go to jail if they do this.

\section{The truth is that the US's position as a leader in this field is at risk; federal policy has really limited us in terms of competing with many foreign countries...}

ER: Is there a lot at stake in this election for your research?

JG: I may be too sensitive to these things, but I think that many researchers in my field feel that McCain has never talked like this before and that he may simply be trying to appeal to his party's more conservative voters. Of course, I feel very strongly about the election, not only in the specific sense of which candidate will give us the most progressive legislative platform, but also in terms of who will be most willing to provide us-and other biomedical researchers-with the funds necessary to carry out our research. I think that in general, the Democrats 
are more inclined to support biomedical research; we have seen large cuts in the NIH's funding throughout the Bush administration and Obama is far more supportive of biomedical research than McCain.

ER: Will there be money available regardless of who wins?

JG: Stem-cell research still garners a great deal of interest in terms of the political and social debate, and many politicians, activists and policy-makers-both for and against it - want to talk about it. We have used this interest to make our way into the political consciousness to begin to talk about funding for stem-cell research specifically and for science in general. I am pleased to say that we have achieved many of our goals in regards to science funding in general, which is extremely important, but it would certainly help and allow us to do more if we had a more progressive science programme at government level.

\section{Many scientists and interested parties feel that we need a more progressive national policy to keep us competitive at the cutting edge of this kind of work}

ER: What sort of regulatory system would you envisage to balance scientific progress, ethical concern and public opinion? Would you favour a central authority, such as in the UK, a blend of state and federal laws, or simply laissez-faire, where anything goes?

JG: I do not think that laissez-faire is the proper way to proceed. There are clearly issues that we have to get our heads around to make practices and legislation uniform throughout the country: how should access to embryos be regulated; what are the conditions under which they can be used in experiments; what is the oversight; what are the safety issues? We have to have some kind of a national oversight on these sorts of things and the National Academy of Sciences [Washington, DC, USA] has recommended the use of ESCROs [Embryonic Stem Cell Research Oversight Committees], which all major institutions that work on ES cells in this country abide by. The Academy has established guidelines that are practical and appropriate, and the NIH could very easily apply these to a national oversight.
However, even with this sort of national oversight, individual states should still be able to set their own policies on what they will and will not permit; we do not need federal legislation saying what can and cannot be done in the whole country, though we perhaps could use federal legislation to determine what can be funded with federal dollars. There are many state laws that currently differ from federal laws, but they are nonetheless constitutional and are working. I think we will always have states that decide they definitely do not want to permit certain things within their borders, but as we are already finding in terms of biomedical research, there is a great divide among states that permit certain kinds of research and those that do not. Naturally, those states that do not permit the research will not have the funding, so things are going to flow into states that do.

ER: Do you think that any areas of stem-cell research and embryology require stronger regulation than others, or even a ban?

JG: I certainly do not think that we should be cloning humans, but I am generally very liberal and progressive. I am mostly concerned with the safety of the research; this is a technology that produces a lot of problems. But, with appropriate oversight-both at the national and institutional levels-1 think that all of the technical and safety issues that concern people can be managed and the ethical debates can be conducted sensibly. My sense is that we do not need legally binding bans on things; most other countries are undertaking stem-cell research at this point and they tend not to have national laws saying what researchers can or cannot do.

ER: Do you think that the ethical and theological objections to using ES cells are fair?

JG: There are certain members of society who are opposed to the use of human embryos in research, owing to their religious and/or philosophical views, and I acknowledge this. However, I think that we, as a society, have a moral obligation to try to provide effective therapies for people who are suffering from disability or disease. Millions of people suffer from illnesses and injuries for which there are no therapeutics available, and ES cells have been an extremely valuable resource in the pursuit of new therapies in my view. I think that we are ethically committed to doing this research.

However, we do have to reach a balance that allows us to pursue this kind of work and acknowledges the views of those opposed to it. Yet, permitting our research does not mean that we will run amok and destroy millions of embryos, which is what our opponents accuse us of wanting to do. I think that extreme views are unhelpful to a true ethical debate in taking this research forward. As scientists, and as members of society, we seek to be ethical in our research and hold ourselves to a high moral standard. To be always pushed into a corner where we must defend against accusations that are untrue and unfair is not correct or helpful.

\section{...I think that we, as a society, have a moral obligation to try to provide effective therapies for people who are suffering from disability or disease}

ER: What message should scientists transmit to gain support for stem-cell research and convince their opponents?

JG: We are not going to convince everybody, nor would we expect to. There are people who are absolutely opposed to stem-cell research and it is their right to hold that opinion. Over time, however, we have managed to educate policy-makers and the public as to what the research really entails and its potential in medical applications. Now, in the various polls, the great majority of Americans supports this work, but only coupled with some kind of oversight. This is particularly important because, as we have learned, a lack of oversight can result in serious problems.

ER: Now that Barack Obama is confirmed to be the next President, what are your thoughts on the future of science and stem-cell research in the US?

JG: The expectations that we have of our new president are enormous in many areas, including science. We anticipate that funding for research will increase, that the vetting of scientists with respect to political views will end, that scientific reports will not be tampered with, that science education will be enhanced, and that overall, 
science will regain respectability in government. This being said, we realize that the current economic realities will limit the investment in science, although Presidentelect Obama has committed to doubling the NIH budget in 10 years. This projection, coupled to his impending change in stem-cell policy-through the removal of President Bush's policy and executive order on stem-cell research and the implementation of a new policy-will certainly enhance our field.

ER: Finally, in hindsight, are you glad to have created the first ES-cell line, knowing how controversial the technology has become?
JG: There were a large number of laboratories around the world that were working on the derivation of human pluripotential stem cells and were minutes away, so to speak, from achieving the same goal. Eventually, someone was going to be successful, and I am glad that we were one of the first two labs to succeed in this endeavour. It is always difficult to think about things in retrospect, but I think the upside of this for me has been far greater than the downside. There I was, working on a little area of science at the lab bench like thousands of my colleagues, and all of a sudden I was successful and the floodlights were turned onto this research area. But, even had I known what was going to happen, I would not have stopped for a minute.

\section{REFERENCES}

Shamblott MJ, Axelman J, Wang S, Bugg EM, Littlefield JW, Donovan PJ, Blumenthal PD, Huggins GR, Gearhart JD (1998) Derivation of pluripotent stem cells from cultured human primordial germ cells. Proc Natl Acad Sci USA 95: 13726-13731

Thomson JA, Itskovitz-Eldor J, Shapiro SS, Waknitz MA, Swiergiel JJ, Marshall VS, Jones JM (1998) Embryonic stem cell lines derived from human blastocysts. Science 282: 1145-1147

The interview was conducted by

Howard Wolinsky.

doi:10.1038/embor.2008.235

Published online 12 December 2008 